\title{
PENGARUH PENERAPAN PRAKTIKUM BERBASIS KEARIFAN LOKAL TERHADAP KETERAMPILAN LITERASI SAINS DAN HASIL BELAJAR
}

\section{THE EFFECT OF THE LOCAL WISDOM BASED PRACTICUM ON THE SCIENCE LITERATION SKILL AND LEARNING OUTCOME}

\author{
Riska Dia Sapitri, Saprizal Hadisaputra, dan Eka Junaidi \\ Program Studi Pendidikan Kimia FKIP Universitas Mataram, Mataram, Indonesia \\ *Email: riskasapitri@gmail.com
}

Diterima: 31 Agustus 2019. Disetujui: 17 September 2019. Dipublikasikan: 2 Maret 2020

\begin{abstract}
Abstrak: Penelitian ini bertujuan untuk mengetahui pengaruh penerapan metode praktikum berbasis kearifan lokal terhadap keterampilan literasi sains dan hasil belajar siswa kelas XI IPA SMAN 3 Sumbawa Besar. Penelitian ini termasuk dalam penelitian eksperimen semu yang menggunakan desain penelitian pre-test posttest control group design. Populasi dalam penelitian ini meliputi seluruh siswa kelas XI IPA SMAN 3 Sumbawa Besar yang berjumlah 130 siswa. Adapun sampel pada penelitian ini yaitu berjumlah 47 siswa. Instrumen yang digunakan berupa angket keterampilam literasi sains dan tes pilihan ganda. Data keterampilan literasi sains (pretest-posttest) dianalisis menggunakan uji $\mathrm{N}$-Gain untuk mengetahui peningkatan keterampilan literasi sains siswa, diperoleh $\mathrm{N}$-Gain kelas eksperimen berkategori sedang 37\% dan kelas kontrol berkategori rendah 25\%. Hasil uji hipotesis data N-Gain keterampilan literasi sains siswa menggunakan uji-t, diperoleh thitung sebesar 2,55 dan ttabel (probabilitas $5 \%$ ) sebesar 1,68, maka thitung >ttabel $(2,55>1,68)$. Data hasil belajar (pretest-posttest) dianalisis menggunakan uji NGain untuk mengetahui peningkatan hasil siswa, diperoleh N-Gain kelas eksperimen berkategori sedang (31\%) dan kelas kontrol berkategori rendah (24\%). Hasil uji hipotesis data N-Gain hasil belajar siswa menggunakan uji-t, diperoleh $t_{\text {hitung }}$ sebesar 1,69 dan $t_{\text {tabel }}$ (probabilitas $5 \%$ ) sebesar 1,68, maka $t_{\text {hitung }}>t_{\text {tabel }}(1,69>1,68)$. Berdasrkan hasil uji-t dapat disimpulkan bawah terdapat pengaruh metode praktikum berbasis kearifan lokal terhadap keterampilan literasi sains dan hasil belajar siswa.
\end{abstract}

Kata Kunci: Praktikum berbasis kearifan lokal, keterampilan literasi sains, hasil belajar.

\begin{abstract}
The study aims to determine the effect of the application of local wisdom-based prakticum method to science literation students' skills and learning outcomes of second grade students in SMAN 3 Sumbawa Besar students. The study was a quasy eksperimental study using a pretest posttest control group design. The studied population was 130 students of second grade SMAN 3 Sumbawa Besar and studied sample was 47 students. The questioner and multilevel choise questions were used as instrument for measuring science literation skills and learning outcomes. The science literation skills and learning outcomes were analyzed using the $\mathrm{N}$-gain test to determine the inprovment of students' science literation skill and learning outcomes. The science litterations skill N-gain for experimental and control class were categoried as madium (37\%) and low (25\%), respectly. The hipotesis was tested used $\mathrm{t}$-test, and it was found that tcount $=2,55$ and $\mathrm{t}$ tebel $=1,68(\mathrm{t}$ count $>\mathrm{t}$ tabel) at $5 \%$ significan. The learning outcomes $\mathrm{N}$-gain for experimental and control class were categoried as madium (31\%) and low (24\%), respectly. The hipotesis was tested used $\mathrm{t}$-test, and it was found that tcount $=1,69$ and $\mathrm{t}$ tebel $=1,68$ ( $\mathrm{t}$ count $>\mathrm{t}$ tabel) at $5 \%$ significan. In conclusion there is influence of the local wisdom-based practicum method on student science literation skills and learning outcome.
\end{abstract}

Keyword: Local wisdom based praktikum, science literation skills, learning outcomes

\section{PENDAHULUAN}

Ilmu kimia merupakan ilmu yang diperoleh dan dikembangkan berdasarkan praktikum, dari praktikum siswa dapat mensinkronisasi antara pembelajaran teori dan praktek terutama pada pembelajaran kimia di SMA [1]. Jika dalam proses pembelajaran kimia hanya didominasi oleh teori tanpa adanya praktek maka tingkat pemahaman siswa pada materi tersebut masih kurang optimal hingga akhirnya siswa menganggap bahwa pelajaran kimia itu sulit [2]. Permasalahan ini dapat diatasi dengan mengembangkan proses pembelajaran yang inovatif dan kreatif sehingga dapat mendorong kemauan siswa dalam belajar. Salah satu metode pembelajaran yang dapat digunakan untuk siswa adalah menerapkan metode praktikum yang berbasis kearifan lokal [3].

Metode praktikum yang berbasis kearifan lokal ini merupakan metode yang memanfaatkan kearifan 
lokal di daerah, khususnya di daerah Sumbawa Nusa Tenggara Barat (NTB) sebagai media dalam proses pembelajaran. Salah satu contoh kearifan lokal yang terdapat di Sumbawa NTB yang digunakan sebagai bahan dalam pembelajaran adalah tradisi "Melala", tradisi melala merupakan tradisi berasal dari Sumbawa, tradisi ini memanfaatkan santan kelapa sebagai salah satu bahan yang harus ada dalam penggunaannya, dimana santan ini jika dikaitkan dengan ilmu kimia pemanfaatan santan dalam tradisi ini berhubungan dengan materi koloid. Metode dan pembelajaran yang berbasis kearifan lokal ini juga didukung dengan kebijakan peraturan daerah provinsi Nusa Tenggara Barat nomor 4 tahun 2015 tentang penyelenggaraan pendidikan dijelaskan pada $\mathrm{Bab} \mathrm{V}$ pasal 19 ayat 1 dan 2 menyebutkan "pemerintah daerah menetapkan standar penyelenggaraan pendidikan yang berbasis kearifan dan keunggulan lokal dengan memperhatikan standar nasional pendidikan sebagai media transformasi budaya pada setiap satuan pendidikan.

Menerapkan metode dan pembelajaran yang berbasis kearifan lokal ini diharapkan dapat mengembangkan berbagai keterampilan yang ada pada siswa. Salah satu keterampilan yang diharapkan adalah keterampilan literasi sains [4]. Terdapat empat aspek keterampilan literasi sains yang bisa diukur yakni sains sebagai batang tubuh pengetahuan (a body of knowledge), sains sebagai cara untuk menyelidiki (a way of investigating), sains sebagai cara untuk berpikir (a way of thinking) dan interaksi antara sains, teknologi, dan masyarakat (interaction between science, technology, and society)[5].

Mengembangkan model pembelajaran berbasis kearifan lokal pernah dilakukan oleh [6] mengembangan perangkat pembelajaran IPA berbasis kearifan lokal untuk meningkatkan kemampuan hasil belajar dan keterampilan berpikir kritis siswa dari penelitian ini menunjukkan perangkat pembelajaran IPA berbasis kearifan lokal yang dikembangkan dalam katagori valid sehingga cukup efektif dalam meningkatkan kemampuan hasil belajar dan literasi sains siswa. Hasil belajar dapat dijelaskan dengan memahami dua kata yang membentuknya, yaitu "hasil" dan "belajar". Pengertian hasil (product) menunjuk pada suatu perolehan akibat dilakukannya suatu aktifitas atau proses yang mengakibatkan berubahnya input secara fungsional. Hasil belajar merupakan perolehan dari proses belajar siswa sesuai dengan tujuan pengajaran (ends are being attained). Tujuan pengajaran menjadi hasil belajar potensial yang akan dicapai oleh anak melalui kegiatan belajarnya [7].

Adapaun keterampilan literasi sains diartikan menurut Hurt sebagai pemahaman atas sains dan aplikasinya bagi kehidupan masyarakat [8]. Literasi sains penting dalam masyarakat modern kita karena banyak masalah yang berkaitan dengan ilmu pengetahuan dan teknologi [9]. Meningkatkan literasi sains melalui pendidikan sains adalah mengembangkan berbagai macam kemampuan dengan memanfaatkan kreativitas pengetahuan dan keterampilan yang tepat berdasarkan bukti ilmiah terutama digunakan untuk memecahkan masalah ilmiah yang menantang dalam kehidupan sehari-hari namun bermakna serta membuat keputusan sosialilmiah yang bertanggung jawab [10].

Metode pembelajaran berbasis kearifan lokal ini juga disesuaikan dengan kondisi siswa di daerah sekitar. Harapannya adalah dengan menerapkan model pembelajaran berbasis kearifan lokal dapat membantu guru pada mata pelajaran kimia dalam membelajarkan peserta didiknya. Hasil lain yang diharapkan dari pengembangan model pembelajaran ini adalah dapat meningkatkan kemampuan literasi sains.

Literasi sains adalah kapasitas untuk menggunakan pengetahuan ilmiah, mengidentifikasi pertanyaan, dan menarik kesimpulan berdasarkan fakta untuk memahami alam semesta dan membuat keputusan dari perubahan yang terjadi karena aktivitas manusia [11]. Seseorang dikatakan memiliki literasi sains jika memiliki tiga kompetensi, yaitu:

1. Menjelaskan fenomena ilmiah; pada kompetensi ini siswa mampu mengakui, memberikan dan mengevaluasi penjelasan dari berbagai fenomena alam dan teknologi.

2. Mengevaluasi dan merancang penyelidikan ilmiah; pada kompetensi ini siswa mampu menggambarkan dan menilai pertanyaan ilmiah serta mengusulkan cara mengatasi pertanyaan ilmiah.

3. Menafsirkan data dan bukti ilmiah; pada kompetensi ini siswa mampu menganalisis dan mengevaluasi informasi ilmiah, pertanyaan dan argumen dalam berbagai representasi serta membuat kesimpulan yang tepat [12].

\section{METODOLOGI PENELITIAN}

\section{Jenis Penelitian}

Jenis penelitian yang dilakukan adalah kuasi eksperimen, yaitu desain yang mempunyai kelompok kontrol, tetapi tidak dapat berfungsi sepenuhnya untuk mengontrol variabel-variabel luar yang mempengaruhi pelaksanaan eksperimen [13]. Dalam penelitian kuasi eksperimen ini didesain menggunakan pretest posttest control group design. Penelitian ini menggunakan teknik pengambilan sampel purposive sampling. yaitu pengambilan sampel dengan pertimbangan tertentu[14].

\section{Populasi dan sampel}


Populasi dalam penelitian ini adalah seluruh siswa kelas XI SMAN 3 Sumbawa Besar berjumlah 130 siswa yang terdiri dari 5 kelas. Masing-masing kelas jumlah siswanya berbeda-beda, kelas XI MIA 1 sebanyak 28 siswa, XI MIA 2 sebanyak 28 siswa, XI MIA 3 sebanyak 26, XI MIA 4 sebanyak 26 siswa, dan kelas XI MIA 5 sebanyak 20 siswa. Berdasarkan teknik purposive sampling ditetapkan bahwa kelas XI MIA 4 sebagai kelas eksperimen dan kelas XI MIA 3 sebagai kelas kontrol dengan jumlah.

\section{Teknik pengumpulan data dan analisis data}

Pada penelitian ini pengambilan data menggunakan instrument tes. Pretest dan posttest yang diberikan akan menghasil data-data penelitian yang dibutuhkan untuk menyimpulkan pengaruh dari metode yang diterapkan. Tes yg diberikan berupa angket sebanyak 20 pertanyaan dan soal pilihan ganda. Angket adalah serentetan pertanyaan atau latihan serta alat lain yang digunakan untuk menganalisis keterampilan, pengetahuan intelegensi, kemampuan atau bakat yang dimiliki oleh individu atau kelompok [15]. Data yang diperoleh diolah dengan beberapa tahap uji berupa uji normalitas, uji homogenitas varians, uji hipotesis, dan analisis kemampuan literasi sains.

\section{HASIL DAN PEMBAHASAN}

Model praktikum Kimia berbasis kearifan lokal adalah salah satu penerapan praktikum yang menggunakan bahan praktikum yang berasal dari tradisis masyarakat sekitar. Selain itu, penerapan praktikum ini juga akan mengkaitkan antara fenomena budaya masyarakat dengan Ilmu Sains khususnya kimia. Siswa tidak lagi menerima secara utuh praktikum yang akan dilaksanakan, akan tetapi siswa harus mencari contoh praktikum yang bisa diangkat pada materi koloid yang berkaitan dengan kearifan lokal daerah setempat. Hal ini akan menciptakan suasana pembelajaran yang lebih bermakna dan pemahaman siswa tentang suatu materi juga akan lebih baik karena materi pembelajaran dikaitkan dengan kebiasaan atau budaya masyarakat.

\section{Keterampilan Literasi Sains Siswa}

Hasil uji hipotesis menggunakan uji-t terhadap keterampilan literasi sains siswa, diperoleh nilai thitung sebesar 2,55 lebih besar dari $t_{\text {tabel }}$ sebesar 1,68 maka Ha diterima dan Ho ditolak. Jadi, terdapat perbedaan keterampilan literasi sains yang signifikan antara siswa yang diajar menggunakan metode praktikum berbasis kearifan lokaldan siswa yang diajar menggunakan metode praktikum berbasis laboratorium. Perbedaan yang signifikan tersebut dapat dilihat dari nilai rata-rata pre-test dan post-test keterampilan literasi sains siswa yang ditunjukkan pada Gambar 1.
Gambar 1 menunjukkan bahwa rata-rata pretest kelas eksperimen dan kontrol tidak jauh beda, yang artinya bahwa kemampuan awal literasi siswa kelas eksperimen dan kontrol sebelum diberikan perlakuan hampir sama. Setelah diberi perlakuan penerapan pembelajaran metode praktikum berbasis kearifan lokal dan metode praktikum berbasis laboratorium, rata-rata keterampilan literasi sains siswa kelas eksperimen dan kontrol mengalami peningkatan. Meskipun kedua kelas sama-sama mengalami peningkatan keterampilan literasi sains, namun rata-rata post-test kelas eksperimen lebih tinggi daripada kelas kontrol dengan selisih 8,71. Nilai ratarata keterampilan literasi sains siswa kelas eksperimen yang tinggi dan memiliki selisih yang cukup besar dari kelas kontrol disebabkan oleh perubahan metode pembelajaran. Metode praktikum berbasis kearifan lokal yang diterapkan pada kelas eksperimen mencakup langkah-langkah pembelajaran yang melatih keterampilan literasi sains siswa [16]. Model pembelajaran ini mampu memberikan kesempatan bagi siswa untuk lebih aktif dalam proses pembelajaran. Siswa didorong untuk mempunyai pengalaman belajar dan melakukan percobaan yang memungkinkan mereka menemukan konsep atau prinsip, sehingga pembelajaran bukan lagi hanya berpusat pada guru memberikan konsep atau prinsip [17].

Analisis lanjutan menggunakan uji N-Gain untuk melihat peningkatan keterampilan literasi sains siswa dari keadaan awal (pre-test) dan keadaan akhir (post-test), diperoleh hasil kelas eksperimen memiliki peningkatan kemampuan literasi sains sebesar 37\% dalam kategori sedang dan kelas kontrol $25 \%$ dalam kategori rendah. Peningkatan kemampuan berpikir kritis kelas eksperimen yang tergolong sedang ini disumbang oleh jumlah siswa kelas eksperimen yang lebih banyak berada pada kategori $\langle\mathrm{g}>$ faktor tinggi dan sedang seperti yangditunjukkan pada Gambar 2.

Gambar 2 menunjukkan bahwa jumlah siswa kelas eksperimen yang tergolong pada peningkatan keterampilan literasi sains siswa tinggi sebanyak 1 siswa dan 13 siswa pada kategori sedang. Berbeda dengan kelas kontrol, hasil peningkatan keterampilan yang tergolong rendah disumbang oleh sebagian besar siswa pada kelas kontrol masuk kedalam kategori $\langle\mathrm{g}\rangle$ faktor rendah yakni sebanyak 13 siswa dengan kisaran $59,1 \%$ dari total seluruh siswa kelas kontrol. Jadi, dari data $\mathrm{N}-$ Gain tersebut diketahui bahwa pembelajaran dengan metode praktikum berbasis kearifan lokal memberikan pengaruh lebih baik terhadap keterampilan literasi sains siswa dibandingkan dengan metode praktikum berbasis laboratorium. Metode praktikum berbasis kearifan lokal memberikan kesempatan kepada siswa untuk aktif dalam menemukan prinsip-prinsip atau pengetahuan melalui 
percobaan dengan menghubungkannya dengan tradisi yang ada dilingkungan mereka, sehingga pelajaran akan lebih bermakna bagi siswa.

Penelitian [16] mengungkapkan bahwa konsep yang diperoleh siswa melalui kegiatan praktikum berbasis kearifan lokal dalam pembelajaran dikelas akan bertahan lebih lama dalam ingatannya. Keterampilan literasi sains siswa lebih berkembang melalui penerapan metode praktikum berbasis kearifan lokal dibanding dengan metode praktikum berbasis laboratorium, karena langkah-langkah dalam metode membuat siswa lebih aktif dalam proses pembelajaran sehingga memungkinkan siswa mampu menguasai aspek-aspek literasi sains. Mengembangan perangkat pembelajaran IPA berbasis kearifan lokal untuk meningkatkan kemampuan hasil belajar dan keterampilan berpikir kritis siswa dari penelitian ini menunjukkanperangkat pembelajaran IPA berbasis kearifan lokal yang dikembangkan dalam katagori valid sehingga cukup efektif dalam meningkatkan kemampuan hasil belajar dan literasi sains siswa. Pada pembelajaran dengan menerapkan metode praktikum berbasis kearifan lokal, siswa terlibat dalam aktivitas kerja kelompok saat melakukan percobaan serta diskusi saat di laboratorium dan kelas [6].

Setiap kelompok beranggotakan lima sampai enam orang sehingga mereka bisa saling bekerjasama untuk menemukan konsep, prinsip, atau jawaban lewat praktikum pada pembuatan praktikum dengan bantuan petuntuk praktikum dan LKS. Pada pembuatan koloid, ada beberapa materi yang masih bersifat abstrak seperti materi proses peptisasi yang berdasarkan konsep pembuatan koloid dengan cara dispersi, sehingga membuat siswa cukup kesulitan untuk memahami materi koloid. Menurut kajian psikologi anak akan lebih mudah mempelajari hal yang konkrit ketimbang yang bersifat abstrak. Hal ini sesuai dengan pembelajaran metode praktikum berbasis kearifan lokal yang didukung dengan praktikum pembuatan koloid mengunakan bahan sehari-hari yang berhubungan dengan tradisi masyarakat setempat seperti belimbing hulu dan santan kelapa sehingga membuat pembelajaran jadi lebih nyata, mengesankan, dan memotivasi siswa untuk menemukan sendiri sehingga pembelajaran jadi bermakna [18].

Pada proses pembelajaran dengan penerapan metode praktikum berbasis kearifan lokal pada pembelajaran membuat siswa mengalami dua pengalaman belajar yaitu pengalaman mental dan pengalaman sosial [18]. Pengalaman mental diperoleh dari indra pendengaran dan penglihatan. Informasi yang didapatkan dari indra pendengaran diperoleh dari penjelasan teman dan arahan guru, sedangkan informasi yang diperoleh dari indra penglihatan berasal dari penemuan siswa itu sendiri. Interaksi yang kuat antara siswa dengan objek kegiatan praktikum dapat mendorong perhatian siswa untuk lebih memahami objek [19]. Penemuan tersebut akan selalu diingat siswa daripada harus mendengar penjelasan dari guru. Pengalaman sosial diperoleh saat siswa berinteraksi dengan teman kelompoknya saat melakukan percobaan dan diskusi kelompok sehingga mereka terlibat aktif dalam proses pembelajaran. Kegiatan diskusi membahas temuan saat percobaan dapat meningkatkan pemahaman siswa. Hal ini disampaikan oleh [20], bahwa dengan belajar bersama siswa dapat meningkatkan pengetahuan dan ketajaman berpikir. Pengalaman yang diperoleh siswa ini digunakan untuk mengambil kesimpulan tentang pembuatan koloid dengan cara peptisasi ditinjau dari konsep pembuatan koloid dengan cara dispersi.

Analisis keterampilan literasi sains dilakukan untuk setiap aspek-aspek keterampilan literasi sains siswa, dengan melihat persentase jawaban siswa pada hasil angket post-test. Dari empat aspek keterampilan literasi sains siswa, siswa kelas eksperimen memiliki persentase yang lebih tinggi daripada kelas kontrol seperti yang ditunjukkan pada Gambar 3.

Pada Gambar 3, persentas literasi sains kelas eksperiman pada aspek 1 dan 4 berada di atas 70,00\%, yang artinya bahwa lebih dari setengah jumlah siswa kelas eksperimen mampu memberikan penjelasan sederhana dan memberikan penjelasan lebih lanjut. Sedangkan persentase literasi sains siswa kelas kontrol masih ada dibawah 70,00 \% yang artinya kelas kontrol mampu mengembangkan kemampuan setelah diterapkan model praktikum berbasis laboratorium (Konvensional).

\section{Hasil Belajar Siswa}

Berdasarkan hasil uji hipotesi uji-t terhadap data hasil belajar pre-test dan post-test, diperoleh hasil thitung sebesar 1,69 lebih besar dari ttabel 1,68 maka Ha diterima dan Ho ditolak. Jadi, setelah dikendalikan oleh kovariat pre-test, terdapat perbedaan hasil belajar yang signifikan antara siswa yang diajarkan menggunakan metode praktikum berbasis kearifan lokal dengan menggunakan metode praktikum berbasis laboratorium (konvensional).

Mengiplementasi model pembelajaran IPA berbasis kearifan lokal untuk meningkatkan kreativitas dan hasil belajar siswa hasil penelitian ini membuktikan bahwa dengan model pembelajaran IPA berbasis kearifan lokal dapat meningkatkan kreativitas dan hasil belajar siswa [21]. Adanya peningkatan hasil belajar pada siswa pada penelitian ini disebabkan oleh beberapa faktor diantaranya, pada kelas eksperimen siswa dapat mengkaitkan antara praktikum yang dilakukan dengan kebiasaan ataupun tradisi didaerah setempat khususnya Sumbawa besar, sedangkan pada kelas kontrol siswa kurang dapat mengakitkan antara 
praktikum yang dilakukan dengan materi yang dipelajari dengan kehidupan sehari-hari, hal ini membutikan bahwa terjadi peningkatan hasil belajar dikelas eksperimen dibandingkan kelas kontrol. Faktor kedua yang mempengaruhi adalah penggunaan bahan kearifan lokal dalam praktikum yang dapat membuat siswa lebih tertarik dan lebih memaknai apa yang mereka pelajari disekolah, dan dari praktikum berbasis kearifan lokal ini menambah pengetahuan baru untuk siswa dalam proses pembuatan minyak kelapa.

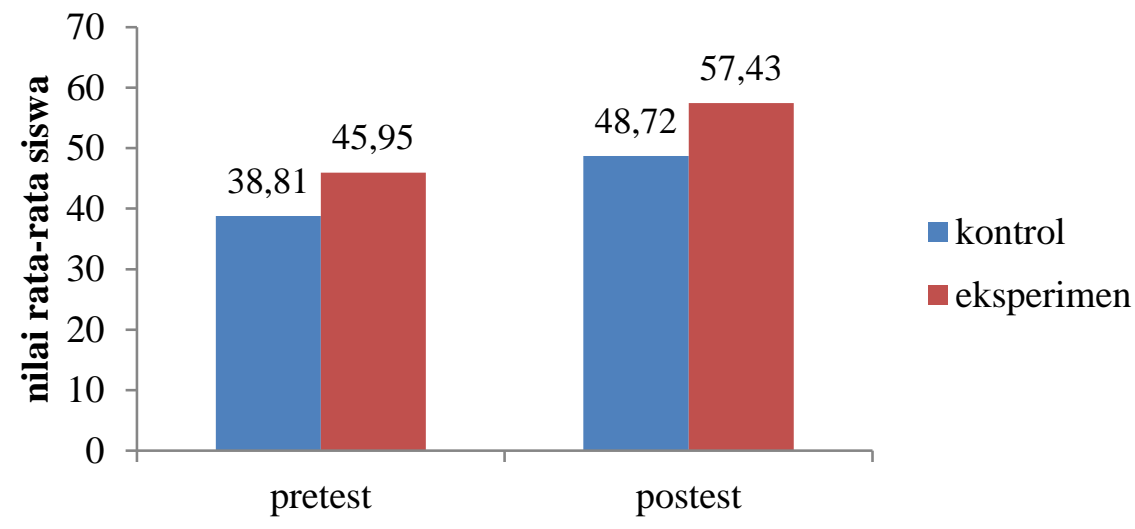

Gambar 1 Hasil Tes (pre-test-posttest) Keterampilan Literasi Sains Siswa Kelas Eksperimen dan Kontrol

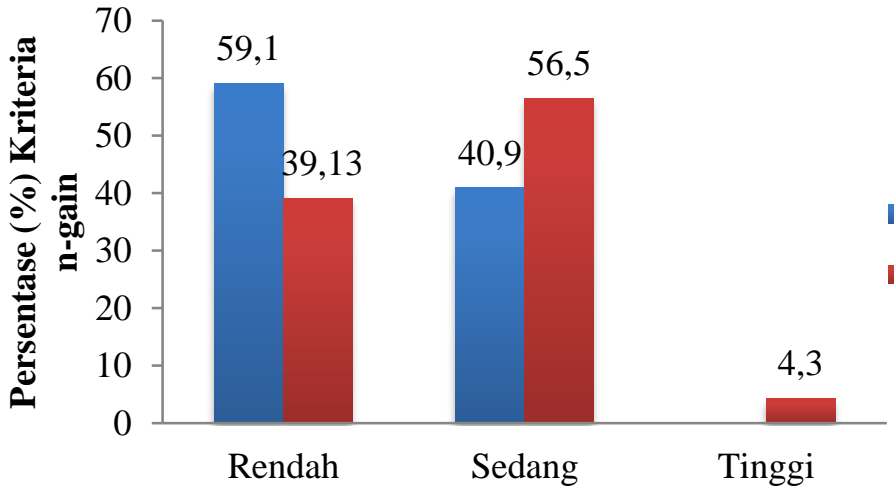

Gambar 2 Kategori <g> Faktor Siswa Kelas Eksperimen dan Kontrol

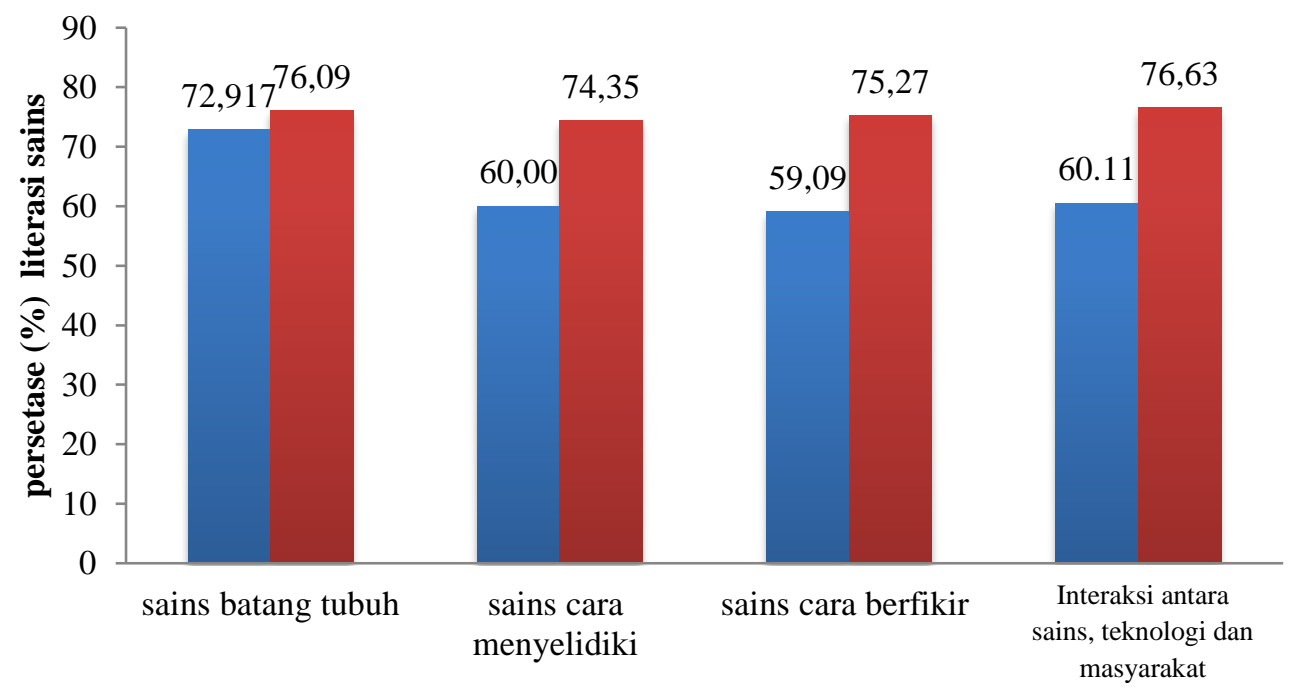

- kelas kontrol

- kelas ekperimen

Gambar 3 Persentase post-test Masing-masing indikator Keterampılan Literası Sains 
Tabel 1 Data Skor Keterampilan Literasi Sains Siswa

\begin{tabular}{lcccc}
\hline \multirow{1}{*}{ Data } & \multicolumn{2}{c}{ Kelas Kontrol } & \multicolumn{2}{c}{ Kelas Eksperimen } \\
\cline { 2 - 5 } & Pre-test & Post-test & Pre-test & Post-test \\
\hline Jumlah Siswa & 22 & 22 & 23 & 23 \\
Rata-Rata & 38,81 & 48,72 & 45,95 & 57,43 \\
Nilai terendah & 25 & 34 & 32 & 35 \\
Nilai tetinggi & 47 & 58 & 57 & 71 \\
\hline
\end{tabular}

Tabel 2 Uji N-Gain Keterampilan Literasi Sains Siswa

\begin{tabular}{lcc}
\hline \multicolumn{1}{c}{ Kriteria } & Kelas Eksperimen & Kelas Kontrol \\
\hline <g $>$ faktor tinggi & $4,43 \%$ & $0 \%$ \\
<g $>$ faktor sedang & $36,1 \%$ & $40,9 \%$ \\
<g $>$ faktor rendah & $56,2 \%$ & $59,1 \%$ \\
\hline & & \\
\hline & Kelas Eksperimen & Kelas Kontrol \\
\hline Rata-rata n-gain & $37 \%$ & $25 \%$ \\
Kriteria $\langle$ g $>$ & Sedang & Rendah \\
\hline
\end{tabular}

Tabel 3 Rata-Rata Keterampilan Literasi Sains Per-Aspek

\begin{tabular}{clcc}
\hline No & \multicolumn{1}{c}{$\begin{array}{c}\text { Aspek Keterampilan Literasi } \\
\text { Sains Siswa }\end{array}$} & $\begin{array}{c}\text { Rata-rata Kelas } \\
\text { Kontrol }\end{array}$ & $\begin{array}{c}\text { Rata-Rata Kelas } \\
\text { Eksperimen }\end{array}$ \\
\hline 1 & $\begin{array}{l}\text { Sains sebagai batang tubuh (a body } \\
\text { of knowledge) }\end{array}$ & $72,91 \%$ & $76,09 \%$ \\
2 & $\begin{array}{l}\text { Sains sebagai cara untuk } \\
\text { menyelidiki (way of investigating) }\end{array}$ & $60,00 \%$ & $74,35 \%$ \\
3 & $\begin{array}{l}\text { Sains sebagai cara berfikir (way of } \\
\text { thinking) }\end{array}$ & $59,09 \%$ & $75,27 \%$ \\
4 & $\begin{array}{l}\text { Interaksi antara sains, teknologi, dan } \\
\text { masyarakat (interaction of science, } \\
\text { technology, and society }\end{array}$ & $\mathbf{6 0 , 5 1 \%}$ & $76,63 \%$ \\
\hline \multicolumn{2}{c|}{ Rata-rata } & $\mathbf{6 6 , 2 0 \%}$ & $\mathbf{7 9 , 3 3 \%}$ \\
\hline
\end{tabular}

Jika dilihat dari perhitungan uji hipotesis menggunkan uji-t bahwa didapatkan t-hitung yang tidak terlalu jauh bedanya dengan t-tabel. Hal ini dikarenakan peningkatan nilai pada kelas eksperimen dapat dikatakan masih rendah ini dapat terlihat hasil nilai n-gain untuk masing-masing kelas eksperimen dan kelas kontrol pada Gambar 4.

Gambar 4 menunjukkan perbandingan nilai $\mathrm{N}$-gain kelas eksperimen dengan kelas kontrol, dari grafik dapat dilihat perbandingan nilai dari kedua kelas untuk siswa yang mendapatkan n-gain rendah lebih banyak dikelas kontrol dibandingkan dengan kelas eksperimen, untuk $\mathrm{N}$-gain kategori sedang nilai pada kelas ekperimen jauh lebih banyak dibandingakan dengan kelas kontrol sedangkan untuk $\mathrm{N}$-gain kategori tinggi untuk kedua kelas tidak terdapat. Tidak terdapatnya nilai $\mathrm{N}$-gain tinggi ini disebabkan oleh beberapa faktor diantaranya tugas yang harus diselesaikan siswa untuk pelajaran lain untuk remidi yang harus dikumpulkan dihari yang bersamaan dengan diberikan soal post-test dikedua kelas, selain itu faktor dari dalam diri siswa, dimana siswa kurang perhatian dalam pembelajaran didalam kelas seperti izin ke kamar mandi atau ke kantin dan tidak kembali lagi ke kelas hal ini membuat siswa tidak dapat memahami materi pembelajaran yang diberikan di dalam kelas. Namun walaupun tidak terdapat nilai $\mathrm{N}$-gain kategori tinggi pada kelas eksperimen ataupun kontrol, namun dari hasil perhitungan uji hipotesis dengan uji-t menggambar terdapat perbedaan yang signifikan antara kelas eksperimen dan kontrol yang dapat diartikan bahawa penerapan praktikum berbasis kearifan lokal dapat meninggkat hasil belajar dan literasi sains siswa kelas XI IPA SMAN 3 Sumbawa Besar. 


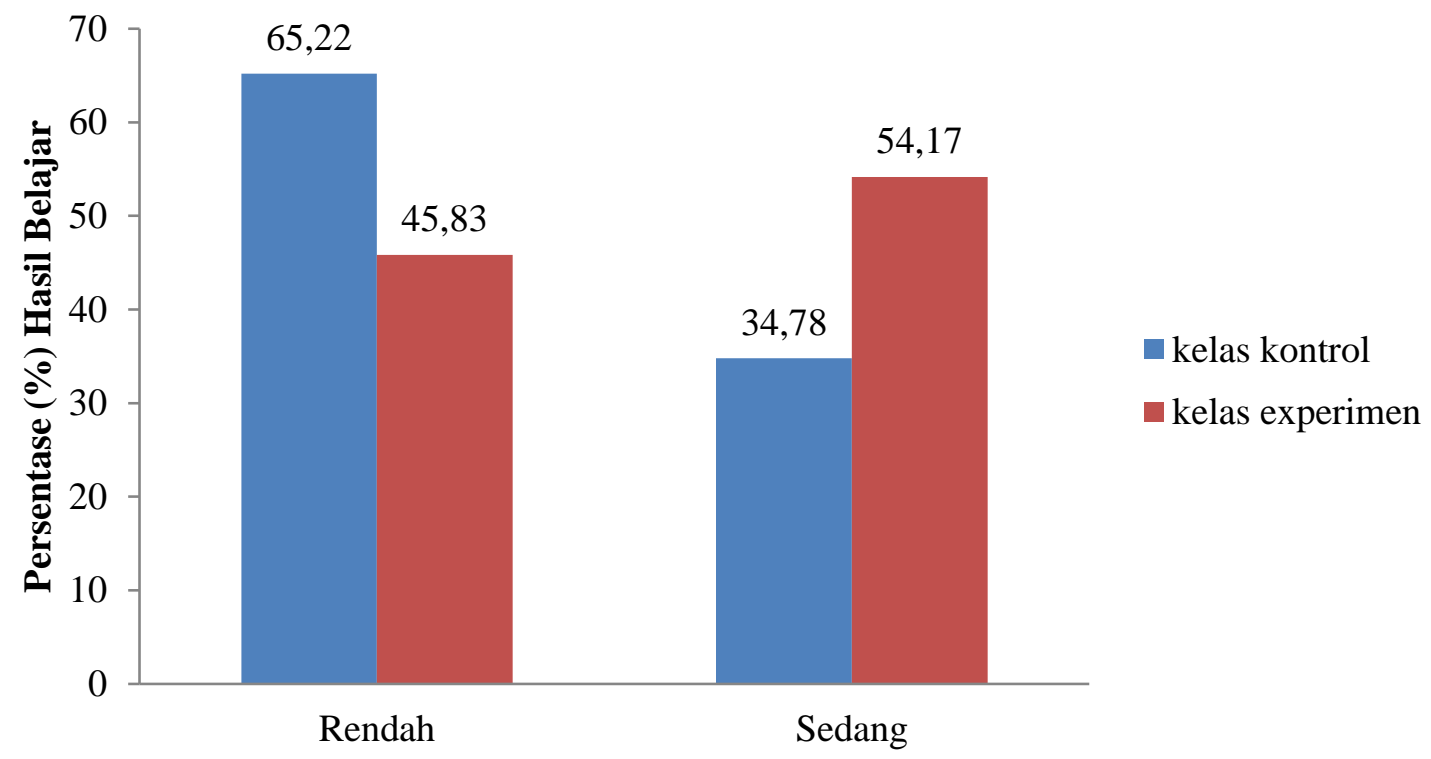

Gambar 4 Perbandingan Nilai n-gain Kelas Eksperimen Dengan KelasKontrol

Tabel 5 Data Hasil Belajar Siswa

\begin{tabular}{lcccc}
\hline \multirow{1}{*}{ Data } & \multicolumn{2}{c}{ Kelas eksperimen } & \multicolumn{2}{c}{ Kelas Kontrol } \\
\cline { 2 - 5 } & Pre-test & Post-test & Pre-test & Post-test \\
\hline Jumlah siswa & 24 & 24 & 23 & 23 \\
Jumlah Siswa tuntas & 0 & 3 & 0 & 1 \\
Ketuntasan Klasikal* & $0 \%$ & $12,55 \%$ & $0 \%$ & $4,35 \%$ \\
Nilai terendah & 16,67 & 31,57 & 16,67 & 31,57 \\
Nilai tinggi & 50,00 & 73,68 & 44,44 & 73,68 \\
Nilai Rata-rata & 37,70 & 57,53 & 37,43 & 52,82 \\
\hline
\end{tabular}

* Perhitungan Klasikal dapat dilihat pada lampiran 26

\section{KESIMPULAN}

Berdasarkan data hasil penelitian dan pembahasan, dapat disimpulkan bahwa terdapat pengaruh penerapan praktikum berbasis kearifan lokal terhadap keterampilan literasi sains siswa dan hasil belajar siswa.

\section{DAFTAR PUSTAKA}

[1] Aji P,Bambang S, Suharto L, 2017. Implementasi Model Pembelajaran IPA Berbasis Kearifan Lokal untuk Meningkatkan Kreativitas dan Hasil Belajar Siswa. Jurnal Inovasi Pendidikan IPA. No 2 Volume 3: 118-127.

[2] Junaidi, E., Hadisaputra, S., Hakim, A., \& Al Idrus, S. W. 2018. Kajian Pelaksanaan Praktikum Kimia Di Sekolah Menengah Atas Di Kabupaten Lombok Barat Indonesia. Jurnal Ilmiah Profesi Pendidikan, 13(1), 24-31.

[3] Asmaningrum H. P. 2017. Analisis Kebutuhan Buku Suplemen Kimia Berbasis Kearifan Lokal Suku Asmat Papua. Prosiding Seminar Nasoinal Kimia dan Pembelajarannya. 681
[4] Ridwan, N. A. 2007. Landasan Keilmuan Kearifan Lokal. Ibda-Jurnal studi Islam dan Budaya, 5(1), 27-38.

[5] Chiappetta, E. L., David A. F., \& Godrej H. S. 1991. A Method to Quantify Major Themes of Scientific Literacy in Science Textbooks. Journal Of Research In Science Teaching, 28(8): 713-725.

[6] Wahyuni S. 2015. Pengembangan Perangkat Pembelajaran IPA Berbasis Kearifan Lokal Untuk Meningkatkan Kemampuan Berpikir Kritis Siswa Jurnal Pendidikan Fisika Indonesia. No. 1 Volume 2 Hal 1-7.

[7] Purwanto. 2014. Evaluasi Hasil Belajar. Yogyakarta: Pustaka Pelajar.

[8] Adisendjaja, Y.H. 2007. Analisis Buku Ajar Sains berdasarkan Literasi Ilmiah sebagai Dasar Untuk memilih Buku Ajar Sains (Biologi). Disampaikan dalam Seminar Pendidikan Nasional di Jurusan Pendidikan Biologi FMIPA. 25-26 Mei 2007. UPI.

[9] Turiman, P., Omar, J., Daud, A.M., \& Osman, K. 2011.Fostering the 21st Century Skills through Scientific Literacy and Science Process 
J. Pijar MIPA, Vol. 15 No.2, Maret 2020: 122-129

DOI: 10.29303/jpm.v15i2.1342

Skills.Procedia - Social and Behavioral Sciences 59 (2012) 110 - 116

[10] Hoolbrook \& Rannikmae. 2009.The Meaning of Scientific Literacy.International Journal of Environmental \& Science Education Vol. 4, No. 3, July 2009, 275-288.

[11] OECD. 2000. Knowledge and Skills for Life: First Results from the OECD Programme for International Student Assessment (PISA) 2000. USA: OECD-PISA.

[12] OECD. 2003. PISA 2009 Assessment Framework: Key Competencies in Reading, Mathematics, and Science. USA: OECD-PISA.

[13] Sugiyono. 2014. Metode Penelitian (Pendekatan Kuantitatif, Kualitatif R\&D). Bandung : Alfabeta

[14] Sugiyono. 2012. Memahami Penelitian Kualitatif. Bandung : Alfabeta.

[15] Arikunto, S. 2010. Prosedur Penelitian Suatu Pendekatan Praktik. Jakarta: Rineka Cipta.

[16] Nofiana M. 2018. Upaya Peningkatan Literasi Sains Siswa Melalui Pembelajaran Berbasis Keunggulan Lokal. Jurnal Tadris Pendidikan Biologi. No.1 Volume 9 Hal 24-25.

[17] Ariningtyas A. 2017. Efektivitas Lembar Kerja Siswa Bermuatan Etnosains Materi Hidrolisis
ISSN 1907-1744 (Cetak)

ISSN 2460-1500 (Online)

Garam untuk Meningkatkan Literasi Sains Siswa SMA. Journal of Innovative Science Education. No. 2 Volume 6 Hal 1

[18] Purwanto. 2012. Evaluasi Hasil Belajar. Yogyakarta: Pustaka Pelajar.

[19] Haris A. Analisis Kemampuan Awal Literasi Sains Siswa Pada Konsep IPA. Jurusan Kimia FMIPA Universitas Negeri Surabaya. No 3 Hal 40.

[20] Sari A.V.D. 2014. Pengaruh Pembelajaran Berbasis Proyek terhadap Kemampuan Literasi Sains Siswa. Pancasakti Science Education Journal. No 2 Volume 2 Hal 114.

[21] Pamungkas, A, Bambang S, Suharto L, 2017. Implementasi Model Pembelajaran IPA Berbasis Kearifan Lokal untuk Meningkatkan Kreativitas dan Hasil Belajar Siswa. Jurnal Inovasi Pendidikan IPA. No 2 Volume 3: 118-127 